\title{
The Themes of 1 Peter: Insights from the Earliest Manuscripts (the Crosby-Schøyen Codex ms 193 and the Bodmer Miscellaneous Codex containing $\mathrm{P}^{72}$ )*
}

\author{
DAVID G. HORRELL \\ Department of Theology and Religion, University of Exeter, Exeter EX4 4RJ, UK \\ email: D.G.Horrell@exeter.ac.uk
}

\begin{abstract}
Recent developments in textual criticism have encouraged NT scholars to regard the various NT manuscripts not merely as sources of variant readings to enable a reconstruction of the original text but as interpretative renderings with their own intrinsic interest and as important material evidence for early Christianity. Taking up this cue, this paper examines what the two (probably) earliest manuscripts of 1 Peter indicate about the status of this writing, and what early readers took to be its key themes, given the other texts with which it is bound. In both cases, and with some striking overlaps, 1 Peter is regarded as a text focused on the Easter themes of the suffering, martyrdom and vindication of Christ, and the related suffering and hope of his faithful people in a hostile world. These two manuscripts also call for some reconsideration of older scholarship, now widely rejected, which saw 1 Peter as a baptismal homily or paschal liturgy. While these remain unconvincing views of 1 Peter's origins, they do rightly identify themes and connections which the earliest editors and readers evidently also perceived.
\end{abstract}

Keywords: 1 Peter, Bodmer Papyrus, Crosby-Schøyen, early NT manuscripts, themes of 1 Peter

\section{Introduction}

Recent developments in textual criticism have significantly broadened the range of insights to be gained from study of the NT manuscripts. While the efforts

\footnotetext{
* I would like to dedicate this essay, first presented as a paper in the month of his retirement after thirty-six years at the University of Exeter, to my colleague Dr Alastair Logan, and to thank him publicly for his warm collegiality (and fruitful discussions of the topic of this paper!). I would also like to thank the following for their very helpful comments and suggestions: Peter Williams, Peter Head, Stuart Macwilliam, Morwenna Ludlow and Lutz Doering. Research for this essay has also been supported by a Small Research Grant from the British Academy, and library facilities in Cambridge and Heidelberg, for which I would also like to express my sincere thanks.
} 
to weigh competing readings and thus establish the earliest form of the text remain crucial, recent studies have shown how the manuscripts (and their variant readings) are themselves valuable embodiments of reception and interpretation, crucial witnesses to early Christianity's visual and material culture. $^{1}$

My interest in this paper is in what are, as things currently stand, very likely the two earliest manuscripts of 1 Peter. Not only does their antiquity make them significant, so also does the character and content of the manuscripts themselves. I am not here concerned with the variant readings of 1 Peter which these two manuscripts present but with the ways in which, as collections of literature, they offer insights into the early interpretation of 1 Peter, the literary connections made with it and what early transmitters of the text of 1 Peter took to be its key themes.

The two manuscripts are the Crosby-Schøyen Codex ms 193 (hereafter C-S), in Sahidic Coptic, and the Bodmer Miscellaneous Codex (hereafter BMC), ${ }^{2}$ in Greek. The Coptic manuscript, as a recently published translational version, has received very little attention in treatments of the text of 1 Peter. ${ }^{3}$ The Bodmer Codex, published in parts between 1958 and 1964, is much better known, at least sofar as its NT items are concerned: it includes 1 Peter, 2 Peter and Jude, known together as $\mathrm{P}^{72}$. However, while the variant readings of $\mathrm{P}^{72}$ have been carefully assessed, ${ }^{4}$ the significance of the manuscript context in which these NT texts appear has less frequently been considered. ${ }^{5}$

Both codices, it should be noted, 'derive from the same early Christian library', ${ }^{6}$ a library of the Pachomian monastic Order, 'discovered late in 1952 in

1 See, e.g., D. C. Parker, The Living Text of the Gospels (Cambridge: Cambridge University, 1997); B. D. Ehrman, The Orthodox Corruption of Scripture: The Effect of Early Christological Controversies on the Text of the New Testament (New York and Oxford: Oxford University, 1993); L. W. Hurtado, The Earliest Christian Artifacts: Manuscripts and Christian Origins (Grand Rapids, MI: Eerdmans, 2006).

2 For this title for the codex, cf. T. Wasserman, 'Papyrus 72 and the Bodmer Miscellaneous Codex', NTS 51 (2005) 137-54.

3 For the publication of the MS, see J. E. Goehring, ed., The Crosby-Schøyen Codex Ms 193 in the Schøyen Collection (CSCO 521; Leuven: Peeters, 1990). Some of the most significant readings of the text of 1 Peter have been presented by a member of the team which edited the codex: H.-G. Bethge, 'Der Text des ersten Petrusbriefes im Crosby-Schøyen-Codex (Ms. 193 Schøyen Collection)', ZNW 84 (1993) 255-67.

4 See, e.g., É. Massaux, 'Le Texte de la $I^{a}$ Petri du Papyrus Bodmer VIII $\left(\mathrm{P}^{72}\right)^{\prime}$, ETL 39 (1963) 616-71.

5 There have been some studies with this latter focus, most recently Wasserman, 'Papyrus 72' and T. Nicklas and T. Wasserman, 'Theologische Linien im Codex Bodmer Miscellani?', New Testament Manuscripts: Their Texts and Their World (ed. T. J. Kraus and T. Nicklas; Leiden: Brill, 2006) 161-88. These have, however, come mostly from those whose primary interest and expertise is in the text-historical/text-critical areas.

6 W. H. Willis, 'The Letter of Peter (1 Peter)', Crosby-Schøyen Codex, 135-215 (137). 
Upper Egypt near Dishnā'. ${ }^{7}$ However, the codices almost certainly date from before the foundation of the Order itself, as does 'much of the material of the highest quality in the collection' ${ }^{8}$ Moreover, their texts of 1 Peter 'appear to be quite unrelated'. ${ }^{9}$ The Greek Vorlage on which C-S depends was evidently quite distinct from-and perhaps considerably older than-that presented in $\mathrm{P}^{72}$ (see below on dating). ${ }^{10}$ The shared geographical provenance of these two codices means that we should be wary of taking them as two entirely unrelated witnesses to the ways in which early Christians collected and interpreted their writings. Nonetheless, the two codices do give us two distinct glimpses into the early reception of 1 Peter. I shall consider each in turn, before drawing some comparative and broader conclusions; I begin with C-S.

\section{Crosby-Schøyen Codex ms 193}

C-S comprises a codex which originally had 136 pages, though these were not numbered sequentially throughout. Each page measures approximately $15 \times$ $15 \mathrm{~cm} .{ }^{11}$ The date of C-S cannot be precisely determined, and opinions range from late second to early fifth century, ${ }^{12}$ but William Willis, the editor and translator of its text of 1 Peter, concludes 'that it may be dated with some confidence to the middle of the III century'. ${ }^{13}$ The Greek Vorlage from which the Coptic translation was made-at a stage prior to the production of C-S itself-must have been older still, quite probably older than the text of $\mathrm{P}^{72} \cdot{ }^{14}$ And whatever its precise date, C-S is undoubtedly an important witness to the early history of the letter.

It is interesting first to note the inscriptio with which 1 Peter begins in C-S

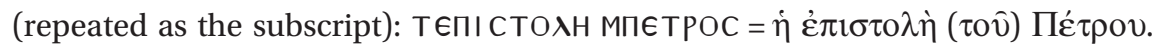
The author of this text, then, and probably the author of the Greek Vorlage too, seems likely to have known-or at least, to have accepted-only this one letter

7 J. M. Robinson, 'The Manuscript's History and Codicology', Crosby-Schøyen Codex (ed. Goehring) xvii-xlvii (xxvii, cf. also xxxv).

8 J. M. Robinson, 'The Pachomian Monastic Library at the Chester Beatty Library and the Bibliothèque Bodmer', Manuscripts of the Middle East 5 (1990-1) 26-40 (27).

9 Willis, 'Letter of Peter', 137.

10 'The Crosby-Schøyen text agrees with only one of the 29 unique significant readings of $\mathrm{P}^{72}$, (Willis, 'Letter of Peter', 137).

11 See Robinson, 'The Manuscript's History', xvii-xlvii, xliii-lxiv.

12 See Robinson, 'The Manuscript's History', xxxiii. K. Aland and B. Aland, Der Text des Neuen Testaments (Stuttgart: Deutsche Bibelgesellschaft, 2nd ed. 1989) 210, suggest 'wahrscheinlich wohl um 400', though with there giving arguments for this date.

13 Willis, 'Letter of Peter', 137, citing support from C. H. Roberts for an early dating in n. 4; Bethge, 'Crosby-Schøyen-Codex', 258-9.

14 Willis, 'Letter of Peter', 138, notes that since C-S is evidently a 'copy of a copy', not itself a direct translation from the Greek, 'the original translation on which it is based must be pushed back to A.D. 200, perhaps even earlier'. 
of Peter. ${ }^{15}$ Moreover, in C-S, 1 Peter does not form part of a collection of NT texts, but a more diverse collection. The texts in their order in the codex, with the likely original pagination, are as follows: ${ }^{16}$

$\begin{array}{ll}\text { Melito of Sardis, On the Passover } & 1-45 \\ 2 \text { Maccabees 5.27-7.41 } & 46-66 \\ 1 \text { Peter } & 1-33 \\ \text { Jonah } & 1-17^{17} \\ \text { Unidentified Text } & \text { [pagination missing] }\end{array}$

Despite the discontinuous pagination, it is evidently all the work of one scribe, ${ }^{18}$ though it seems likely that the very fragmentary final homily was added at a later stage (but still by the same scribe). ${ }^{19}$ The collection of texts evidently makes no distinction between 'canonical' texts and others.

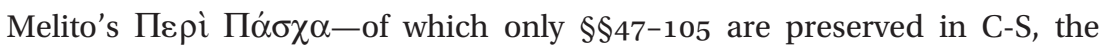
opening sections being lost-focuses on the story of the Passover lamb as a prefiguration of the redemptive sufferings of Christ. Also notable in combination with the Passover lamb motif is the use of the Isaianic suffering servant material, particularly its sheep/lamb imagery (quoted explicitly in \$64; see also, e.g., \$\$4, 8, 44, 71). The deliverance purchased for the members of the Church-'from slavery to freedom, from death to life, from tyranny to everlasting kingdom' ( $\$ \$ 67-68$ $[\mathrm{C}-\mathrm{S}]^{20}$ ) - gives them a new identity which is described in terms drawn again from OT texts in Exodus (19.6) and Isaiah (43.20): 'he made us a new priesthood and a chosen people and an eternal kingdom' ( $\$ 68[\mathrm{C}-\mathrm{S}]) .{ }^{21}$ This is also a striking and precise parallel to 1 Pet 2.9 .

15 Willis, 'Letter of Peter', 146; Bethge, 'Crosby-Schøyen-Codex', 260. Eusebius clearly knows of

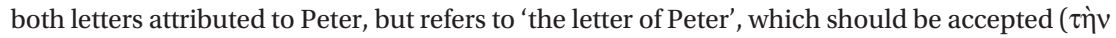

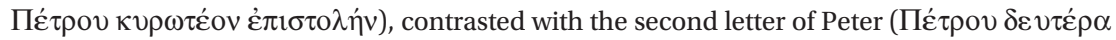
$\dot{\varepsilon} \pi 1 \sigma \tau \mathrm{\lambda} \eta \dot{\eta})$ which is among the disputed books (HE 3.25.2-3). I am grateful to Peter Head for alerting me to this point.

16 There may possibly have been a brief opening tractate, but since the opening pages of the codex are missing, it is impossible to know what, if anything, might have filled these opening pages. The extant pagination for Melito (which begins only at p. 17, the previous pages being mostly lost), suggests a separately paginated six-page section at the beginning of the codex. See Robinson, 'The Manuscript's History', xlvi; J. E. Goehring and W. H. Willis, 'On the Passover by Melito of Sardis', Crosby-Schøyen Codex (ed. Goehring) 1-79 (4).

17 However, the text of Jonah begins, prior to p. 1, on the same page (p. 33) as the ending of 1 Peter (see plate 8 in Goehring, ed., Crosby-Schøyen Codex).

18 See J. E. Goehring, 'The Manuscript's Language and Orthography', Crosby-Schøyen Codex (ed. Goehring) xlix-lxii.

19 J. E. Goehring, 'Unidentified Text', Crosby-Schøyen Codex (ed. Goehring) 261-75 (263).

20 ET from Goehring and Willis, 'On the Passover', 43.

21 These words are missing from the text of Melito in the Bodmer Papyrus, on which see below, and fall within a lacuna in the Latin text. See O. Perler, Méliton de Sardes: sur la Pâque, 
Indeed, there are a number of close parallels between 1 Peter and Melito, at the level both of terminology and theme, and of more exact literary parallels, close enough to allow the possibility of, if not prove, literary dependency. ${ }^{22}$ More generally, 1 Peter and Melito's Peri Pascha represent a common interpretation of the death of Christ in terms drawn both from the Exodus Passover account and Isaiah 53. This, John Elliott suggests, points at least to a shared oral tradition of interpretation (and possibly to Melito's knowledge of 1 Peter). ${ }^{23}$

The second text is an extract from 2 Maccabees, the 'martyrology section' of the book. ${ }^{24}$ Its title in C-S is 'The Martyrs of the Jews Who Lived Under Antiochus the King', abbreviated in the subscript to 'The Jewish Martyrs'. ${ }^{25}$ According to the editors, 'though on the whole it seems to parallel Septuagint 2 Maccabees closely, it often gives a paraphrase or digest, or chooses a different word' ${ }^{26}$

This section of 2 Maccabees describes the persecution of Jews which followed the king's demand that they join in the offerings and celebrations associated with his birthday, actions which are taken to represent the acceptance of Greek customs (6.7-9). First two women are publicly paraded and killed for having circumcised their sons (6.10). Then we hear about the hideous deaths of Eleazar, and of seven brothers and their mother, who refused to eat pork and thus defile themselves. The text was especially important, Jonathan Goldstein notes, since it contained 'the earliest surviving examples of elaborate stories of monotheists suffering martyrdom' and as such provided 'the direct source for the patterns that thereafter prevailed in Jewish and Christian literature'. ${ }^{27}$

After 1 Peter, the fourth text to be found in C-S is a complete text of Jonah, entitled 'Jonah the Prophet'. The text again closely follows the Septuagint, with some variations, mostly due 'to the simple preferences of the translator'. ${ }^{28}$

et Fragments (SC 123; Paris: Cerf, 1966) 98, 173. There is therefore some uncertainty about their originality, but they are, significantly, present within the C-S text.

22 Along with Melito 68//1 Pet 2.9, Melito 12//1 Pet 1.19 is also an especially precise parallel, where the shared terminology might well reflect the influence of 1 Peter on Melito. See J. H. Elliott, 1 Peter (AB 37B; New York: Doubleday, 2000) 145-6.

23 Elliott, 1 Peter, 145, who details further parallels.

24 See E. S. Meltzer and H.-G. Bethge, 'The Jewish Martyrs (2 Maccabees 5:27-7:41)', CrosbySchøyen Codex (ed. Goehring) 81-133 (83), who note that the other known Coptic ms of 2 Maccabees includes virtually the identical section (5.27-7.21, possibly running to 7.41 in its original complete form).

25 Meltzer and Bethge, 'The Jewish Martyrs', 83.

26 Meltzer and Bethge, 'The Jewish Martyrs', 84.

27 J. A. Goldstein, II Maccabees: A New Translation with Introduction and Commentary (AB 41A; New York: Doubleday, 1983) 282.

28 C. W. Hedrick, 'Jonah the Prophet (Jonah)', Crosby-Schøyen Codex (ed. Goehring) 217-59 (220). 
According to Charles Hedrick, editor and translator of the C-S text of Jonah, "[t]he relatively numerous remains of the Coptic text of Jonah suggest that it played a significant role in the liturgical life of early Coptic Christianity particularly in Upper Egypt'. ${ }^{29}$ The story of Jonah was also 'an overwhelmingly favorite subject' in early Christian art, appearing 'more than seventy times...[i]n the preConstantinian era', often with several episodes from the narrative depicted. ${ }^{30}$ The earliest such example is in the third-century Callistus Catacomb in Rome. ${ }^{31}$ The images of Jonah in early Christian art help to indicate one major reason for the story's popularity: its perceived relevance as a type of the Easter story, a sign of resurrection, notably in the 'three days and three nights' (2.1) Jonah spends inside the fish. ${ }^{32}$ This christological parallel is strengthened further by the implication that Jonah has, in this three-day period, indeed gone to the

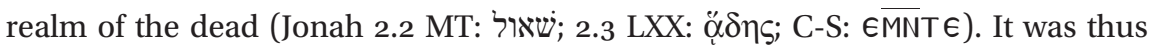
also appropriate as a symbol of the resurrection hope for the deceased whose place of repose it marked, as they awaited the final day of resurrection.

The typological significance of the Jonah story seems to have been picked up very early in the Christian tradition. A saying recorded in both Matthew and Luke makes reference to 'the sign of Jonah' ( $\tau$ ò $\sigma \eta \mu \varepsilon i ̂ v ~ ' I \omega v \hat{\alpha}:$ Matt 12.39; 16.4; Luke 11.29). Matthew's version-which describes Jonah, like the inscriptio in C-S, as Jonah 'the prophet' (12.39) - most clearly indicates that the sign refers to the Easter events, since it contains the crucial comparison, 'just as Jonah was three days and three nights in the belly of the sea-monster, so will the Son of Man be three days and three nights in the heart of the earth' (v. 40). As such, the sign of Jonah can equally well be applied to the general Christian hope for resurrection, as in 3 Cor 3.29-31 (a text, incidentally, which appears in the second of our codices; see below).

There are perhaps other reasons too why the text of Jonah may have appealed to readers who also treasured 1 Peter: it is a story about a righteous man (1.14) called to missionary witness in a world of wickedness and vice (1.2). Indeed, one possible interpretation of 'the sign of Jonah' as presented and interpreted in Luke $11.29-30$ is of Jonah, like Jesus, as a preacher of repentance. ${ }^{33}$ Because of Jonah's witness to the Lord, the sailors-who nobly seek to avoid causing the

29 Hedrick, 'Jonah the Prophet', 219.

30 R. M. Jensen, Understanding Early Christian Art (London and New York: Routledge, 2000) 69, 172.

31 For a colour picture, see L. V. Rutgers, Subterranean Rome: In Search of the Roots of Christianity in the Catacombs of the Eternal City (Leuven: Peeters, 2000) 93.

32 See Jensen, Early Christian Art, 171-4. Cf. Justin Dial. 107; Origen Comm in Matt 12.3; Basil De Spiritu Sanc. 14.32.

33 An older view discussed and rejected by Jeremias, 'I $\omega v \hat{\alpha} \varsigma^{\prime}, T D N T$ 3.409. J. B. Green, The Gospel of Luke (NICNT; Grand Rapids, MI: Eerdmans, 1997) 464, nonetheless sees this still as one of two possibilities that make good sense in the narrative. 
death of a righteous man (1.14) — are converted to worshipping God (1.16), as are the inhabitants of Nineveh (3.5-8), much to Jonah's chagrin. Jonah's prayer to God in the midst of his affliction (2.2-9) is especially apposite for those who are suffering affliction, even to death, but who look to God as the source of their salvation. These are central themes in 1 Peter too: the missionary witness of God's people in a hostile world and their related afflictions, and their hope for vindication and salvation (cf. 1.3-9; 2.12; 3.15-16).

The final text included in the codex is fragmentary and as yet unidentified. Differences in presentation (one column of text per page, compared with two throughout the rest of the codex; no apparent title or subscript) suggest that it 'represents a secondary addition to an original collection of four tractates', though it is 'written in the same scribal hand'. ${ }^{34}$

Too little of the text is extant to analyse its content in any detail. It 'exhorts its hearers to prayer, action and watchfulness', ${ }^{35}$ drawing on biblical images and allusions to do so (e.g., references to the good shepherd $[125,7] ;^{36}$ to virgins and their lamps [126, 2-4]; to Noah and Joseph [126, 6, 12]). The rhetorical style has been seen as reminiscent of Melito, though this is insufficient basis to conclude that he was the author. ${ }^{37}$ The style seems to suggest that the text takes the form of a homily, though some other form of exhortation or catechesis is also possible. ${ }^{38}$

It is evident that C-S has a clear thematic coherence, focused around the Easter themes of suffering and vindication. ${ }^{39}$ Hans-Gebhard Bethge summarises the themes concisely as 'Leiden, Passion, Ostern' ${ }^{40}$ More fully, we might say that the collection focuses on the paschal suffering of Christ (esp. in Melito), and the suffering (and martyrdom) of God's people (esp. in 2 Maccabees), and, more generally, the existence and mission of Christians in a hostile gentile world (cf. Jonah, also a key Easter parable). It is striking how well these themes also reflect those central to 1 Peter. Indeed, given the way in which 1 Peter contains and connects all the above themes, we might well argue that it is perhaps the central text in terms of the thematic coherence of the codex. 1 Peter, like Melito's Peri Pascha, which it may have influenced, draws on both Exodus Passover and Isaianic suffering servant material to depict the suffering and sacrifice of Christ $(1.2,19 ; 2.21-25) .1$ Peter is clearly addressed to Christians who are suffering

34 Goehring, 'Unidentified Text', 263.

35 Goehring, 'Unidentified Text', 264.

36 The text is cited according to the codex page number then line number(s), following the convention in Goehring, 'Unidentified Text'.

37 See Goehring, 'Unidentified Text', 263 with n. 2, 264 with n. 5; A. Stewart-Sykes, The Lamb's High Feast: Melito, Peri Pascha and the Quartodeciman Paschal Liturgy at Sardis (VTSup 42; Leiden: Brill, 1998) 180.

38 Goehring, 'Unidentified Text', 264.

39 Willis, 'Letter of Peter', 137.

40 Bethge, 'Crosby-Schøyen-Codex', 257. 
due to the hostility of the world around them, suffering not only informal slander and opprobrium but also, on occasion, trials and executions for confessing the name 'Christian'. ${ }^{41}$ And Christ's path of suffering is presented as an example, a way of discipleship (2.21), which leads to glory and salvation $(1.3-12,21 ; 4.1-2$; 5.10). C-S clearly shows that early readers indeed took these to be the central themes of 1 Peter, linking it with other texts that depicted the paschal sufferings of Christ and the suffering of God's people.

\section{The Bodmer Miscellaneous Codex}

The Bodmer Miscellaneous Codex is more complex to assess. For a start, it has not been preserved in its assembled form, and was published in a number of separate volumes in the Papyrus Bodmer series. ${ }^{42}$ The codex contains the work of several scribes and was formed by the amalgamation of a number of previously distinct writings. ${ }^{43}$ The order and contents of the codex thus remain somewhat open to debate. ${ }^{44}$ Nonetheless, we can be highly confident that these texts were collected together to form one codex, originally containing around 190 pages in total. ${ }^{45}$ The papyrus sheets measure around $28 \mathrm{~cm} \times 15.5 \mathrm{~cm}$, giving a page size of $14 \times 15.5 \mathrm{~cm},{ }^{46}$ similar to that of C-S.

Connections in the pagination or evident in the preserved manuscripts enable some of the links between texts in the collection to be confirmed beyond doubt. There were clearly a number of scribes involved, and the most recent work by

41 A good deal of recent scholarship has concluded that 1 Peter reflects mostly informal opprobrium and public hostility, not trials and possible executions, but I think that both scenarios, connected through the accusatorial process, are likely in view. See D. G. Horrell, 'The Label

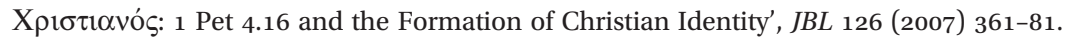

42 Papyrus Bodmer V, VII, VIII, IX, X, XI, XII, XIII, XX (Cologne-Geneva: Bibliotheca Bodmeriana, 1958-64). A new edition of the Apology of Phileas has since been published: A. Pietersma, The Acts of Phileas Bishop of Thmuis (Including Fragments of the Greek Psalter): P. Chester Beatty $X V$ (with a New Edition of P. Bodmer XX, and Halkin's Latin Acta) (Cahiers d'orientalisme 7; Geneva: Victor Chevalier, 1984).

43 See M. Testuz, Papyrus Bodmer VII-IX (Cologne-Geneva: Bibliotheca Bodmeriana, 1959) 9, who suggests that the texts must have existed 'en plusiers brochures séparées, qu'on a réunies en un seul livre'.

44 Cf. Testuz, Papyrus Bodmer VII-IX, 9; V. Martin, Papyrus Bodmer XX (Cologne-Geneva: Bibliotheca Bodmeriana, 1964) 9; E. G. Turner, The Typology of the Early Codex (Pennsylvania: University of Pennsylvania, 1977) 80; Wasserman, 'Papyrus 72', 140-5; Nicklas and Wasserman, 'Theologische Linien', 161-7.

45 For the estimate of ca. 190 pages, see W. Grunewald and K. Junack, Das Neue Testament auf Papyrus. I: Die katholischen Briefe (ANTF 6; Berlin and New York: de Gruyter, 1986) 17. Testuz, Papyrus Bodmer VII-IX, 8-9, estimated ca. 180 pages, prior to the reconstruction of the Apology of Phileas. My own count from the various Bodmer Papyrus volumes brings a total of around 190 pages, of which 183 are extant.

46 Martin, Papyrus Bodmer XX, 7; Testuz, Papyrus Bodmer VII-IX, 9. 
Tommy Wasserman presents a strong case for identifying five distinct hands. ${ }^{47}$ But the codicological connections indicate three distinct sections, two of them connected by a common scribe. ${ }^{48}$ The contents of the codex in the order proposed by Michel Testuz, editor of the majority of the relevant Papyrus Bodmer volumes, are as follows; I have also indicated the three sections of the codex as numbered by Winfried Grunewald (and later Wasserman), and the likely scribal hands. ${ }^{49}$

\author{
I Nativity of Mary (=Protevangelium of James) [scribe A] \\ [scribe B] \\ I Odes of Solomon 11 [scribe B] \\ I The Epistle of Jude [scribe B] \\ I Melito of Sardis, On the Passover [scribe A or E] \\ I Fragment of a liturgical hymn [scribe A or E] \\ II Apology of Phileas [scribe C] \\ II Psalms 33-34 LXX [scribe D] \\ III 1 and 2 Peter [scribe B]
}

I Apocryphal Correspondence of Paul with the Corinthians (3 Corinthians)

The creation of the codex in its final form, Grunewald suggests, was occasioned by the martyrdom of Phileas (in 304-307 CE) $:^{50}$ this was the impetus to construct a collection with the Apology of Phileas (and Pss 33-34, undoubtedly part of the same text as the Apology) as its core. ${ }^{51}$ The earlier collections (I and III), dating probably from the third century, ${ }^{52}$ may have been supplemented and drawn together into a new codex in the early fourth century. ${ }^{53}$

This means, of course, that the text of 1 Peter as preserved in this codex has a number of contexts, at different stages of the growth of the collection. ${ }^{54}$ The first stage is its grouping with 2 Peter in a distinct manuscript (section III). In contrast to C-S, we here find the letter entitled $\pi \varepsilon \tau \rho \circ v \varepsilon \dot{\varepsilon} \pi \sigma \tau о \lambda \eta \alpha^{\prime}$ and linked with a

47 Wasserman, 'Papyrus 72', 148-54.

48 See Testuz, Papyrus Bodmer VII-IX, 9.

49 See Testuz, Papyrus Bodmer VII-IX, 8-9; Grunewald and Junack, Die katholischen Briefe, 19; Wasserman, 'Papyrus 72', 142-6; Nicklas and Wasserman, 'Theologische Linien', 162, 165-6, though Nicklas and Wasserman suggest that the order of texts in the codex may have been different from that proposed by Testuz, with the Apology of Phileas (and Pss 3334 ) at the beginning or the end of the collection.

50 On the possible date range for the martyrdom, see Martin, Papyrus Bodmer XX, 10; Pietersma, Acts of Phileas, 14.

51 Grunewald and Junack, Die katholischen Briefe, 23-4.

52 For the third-century dating, see, e.g., Testuz, Papyrus Bodmer VII-IX, 9, and Papyrus Bodmer $V, 10$.

53 Cf. W. Wiefel, 'Kanongeschichtliche Erwägungen Zu Papyrus Bodmer VII/VIII (P72)', Archiv für Papyrusforschung 22 (1973) 289-303.

54 Cf. esp. Wiefel, 'Kanongeschichtliche Erwägungen'. 
second letter attributed to the same apostle, a link suggested already by the explicit reference to a previous letter in 2 Pet 3.1. This manuscript, then, provides an early example of the kind of 'Petrine witness' which Robert Wall suggests is the canonical function of 2 Peter, when placed alongside 1 Peter. ${ }^{55}$ The combination of 1 and 2 Peter provides a fuller depiction of emerging orthodoxy, and a clear opposition to 'false' teachers (a dominant concern in 2 Peter), presented under the name of the apostle who represented the 'rock' on which the church was built (Matt 16.18).

Indeed, this interpretation of the significance of the grouping of 1 and 2 Peter can be strengthened when we consider the marginal headings, or thematic summaries, that occur through 1 and 2 Peter but nowhere else in the BMC. ${ }^{56}$ This feature of the Petrine texts of the BMC, Wolfgang Wiefel suggests, is an indication of the particular value placed upon these writings, compared with others in the collection. ${ }^{57}$ It is indeed striking that it is only in these two letters that these marginal notes appear. This may be explicable, however, on the grounds that this particular tract, containing only 1 and 2 Peter, was first produced separately, before being incorporated into the larger codex. What seems more persuasive is Wiefel's suggestion that these headings offer 'Hinweise, die ein Stück Hermeneutik sichtbar werden lassen' ${ }^{58}$ In other words, these marginal summaries indicate for us, as for the early readers of the codex, something of what were taken to be the main topics of the two letters. They are as follows (preserving the spellings in BMC):

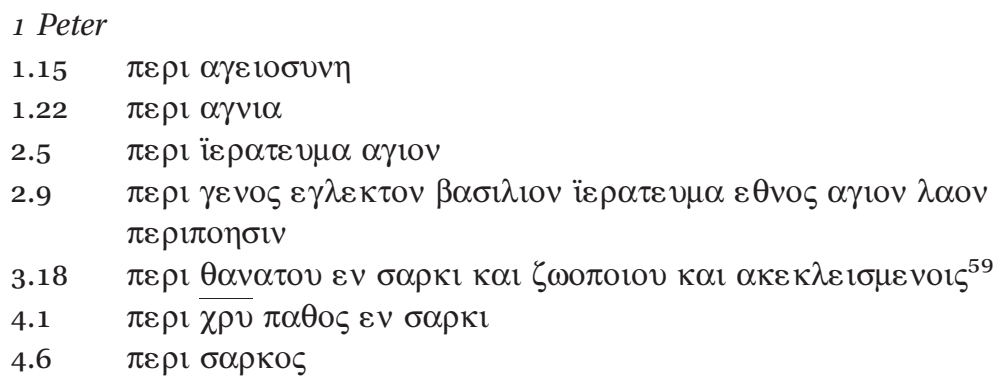

55 R. W. Wall, 'The Canonical Function of 2 Peter', BibInt 9 (2001) 64-81.

56 These are presented in their marginal location in the text of $\mathrm{P}^{72}$ edited by Testuz, and are listed and discussed by Wiefel, 'Kanongeschichtliche Erwägungen', 301; Grunewald and Junack, Die katholischen Briefe, 21; Nicklas and Wasserman, 'Theologische Linien', 183-4.

57 Wiefel, 'Kanongeschichtliche Erwägungen', 301.

58 Wiefel, 'Kanongeschichtliche Erwägungen', 301.

59 F. W. Beare, The First Epistle of Peter (Oxford: Blackwell, 3rd ed. 1970 [1947]) 4, suggests that this is probably an error for $\kappa \alpha \tau \alpha \kappa \varepsilon \kappa \lambda \eta \sigma \mu \varepsilon v 01 \varsigma$ which is read by $\mathrm{C}$ and a few minuscules, and is widely represented in the Old Latin' (and also the Syriac Peshitta and Ethiopic versions). Indeed, $\mathrm{P}^{72}$ 's marginal note may thus be a very early witness to the presence of this word in the textual tradition. Given the (Coptic) scribe's relatively poor Greek, it is unlikely he introduced this word without some influence or precedent. 


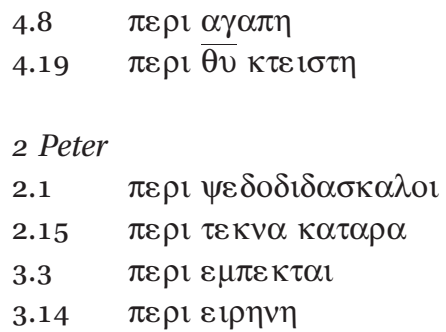

As Wiefel points out, these summary phrases together give a clear indication of the priorities of Christian life in the world: holiness and purity, the holy priesthood and chosen people of God, belief in the sufferings of Christ in the flesh and in the creator God, separation from false teachers and scoffers, love and peace. In short, Wiefel claims, 'das Bild eines durchschnittlichen großkirchlichen Christentums tritt uns aus diesen Überschriften entgegen' ${ }^{60}$ This rather exaggerates the extent to which the headings themselves constitute a mini-summary of the key aspects of orthodox early Christianity, especially given their rather poor Greek, except insofar as 1 and 2 Peter together themselves constitute such an orthodox Bild. But whatever their combined doctrinal force, the summary notes certainly reflect an interpretative reading of the text which, by identifying and summarising topics, influences subsequent readings. More specifically, for 1 Peter in particular, it is interesting to note that by far the two longest marginal notes relate to the declaration of the identity of the new people of God (2.9) - a verse, we recall, closely paralleled in Melito-and the death and new life of Christ, in the context of his enigmatic proclamation to the imprisoned spirits (3.18; cf. also the heading to 4.1 on this theme). This focus of attention in the thematic summaries gives a further indication of what was seen as the theological centre of the epistle.

The tract containing 1 and 2 Peter was combined with another collection of texts (section I of the codex), some written by the same scribe, containing the Nativity of Mary, 3 Corinthians, the 11th Ode of Solomon, the letter of Jude, Melito's Peri Pascha and a liturgical hymn. It is interesting to note, first, the linking of 1-2 Peter with Jude, a hint as to the early stages in the clustering of 'catholic epistles', ${ }^{61}$ and second, that here we find these subsequently canonised writings grouped with other early Christian literature, with no evident distinctions of status or value. ${ }^{62}$

It is difficult, however, to see any close thematic connections to explain the bringing together of this collection of texts, though this is an issue to which we shall shortly return. The inclusion of Jude might well be explained either on the

60 Wiefel, 'Kanongeschichtliche Erwägungen', 302.

61 Cf. Wiefel, 'Kanongeschichtliche Erwägungen', 293-6.

62 Cf. Wiefel, 'Kanongeschichtliche Erwägungen', 297-8. 
grounds of the status of its author ${ }^{63}$ or because of the evident similarity of its material with that of 2 Peter (there is a large amount of closely shared material suggesting clear literary dependence). But it is hard to see any reason, in terms of closely shared theme or common outlook, for linking these three texts with the Nativity of Mary, 3 Corinthians and the 11th Ode of Solomon.

It may be that a concern for mainstream orthodoxy, and defence against socalled heresies, was a prominent motivation. Jude, like 2 Peter, is dominated by a polemical denunciation of false teachers. The Nativity of Mary (ProtJas), the opening tract in section I, is clearly concerned to stress the purity and virginity of Mary, and the virginal conception of Jesus, drawing especially on Luke's nativity story (ProtJas 11.1-6; 19.1-20.4), thus, among other things, countering any low or adoptionist Christology. It is interesting to note that three unique readings in $\mathrm{P}^{72}$ also indicate a concern to stress the deity of Christ, perhaps again with an antiadoptionist motivation: in Jude 5, instead of אvploৎ (where some MSS, including

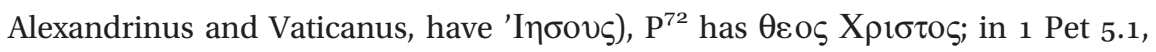

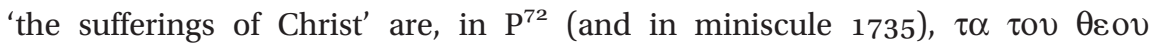
$\pi \alpha \theta \eta \mu \alpha \tau \alpha$; and in 2 Pet 1.2 , the omission of $\kappa \alpha$ l leads to the reading $\dot{\varepsilon} v$

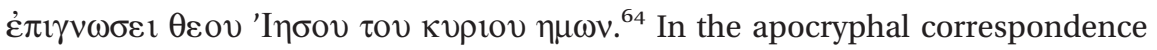
of Paul with the Corinthians, Paul is called upon in order to oppose false teachers, who deny, among other things, God's omnipotence, creation of the world, the real humanity of Christ and the resurrection from the dead (3 Cor 1.9-15). The eleventh Ode is perhaps the most difficult to connect thematically, ${ }^{65}$ though James Charlesworth has recently suggested that it may have been found valuable in further stressing a belief in resurrection and future life, with its depiction and promise of paradise (OdeSol 11.16-19, 23-24). Charlesworth also notes a link between Jude's polemic against false teachers who are like fruitless trees (Jude 12) and the positive depiction of the blossoming fruitful trees in the land of eternal life' (OdeSol 16.a-c, unique to the PBod text). ${ }^{66}$

One thing that is striking about the contents of sections I and III of the codex is the appearance of Melito's Peri Pascha alongside 1 Peter, as in C-S. The fragment

63 On Jude's significance in the leadership of early Jewish Christianity, see R. J. Bauckham, Jude and the Relatives of Jesus (Edinburgh: T. \& T. Clark, 1990). This significance may have been particularly important in the context of a Catholic Epistle collection, the purpose of which was, at least in part, to counterbalance the influence of the Pauline Epistle collection: see D. R. Nienhuis, Not by Paul Alone: The Formation of the Catholic Epistle Collection and the Christian Canon (Waco, TX: Baylor University, 2007).

64 See Wasserman, 'Papyrus 72', 152-3. More generally, on this issue, see Ehrman, Orthodox Corruption of Scripture.

65 A point made emphatically by Nicklas and Wasserman, 'Theologische Linien', 175.

66 J. H. Charlesworth, 'Bodmer Papyrus and Ode of Solomon 11: What Function or Functions Did the Collection Serve?', Paper presented at the SBL Annual Meeting, Boston MA, November 2008. 
of a hymn that immediately follows the Peri Pascha is too brief to say very much about. It is clearly some kind of liturgical hymn, its call to praise and response suggesting the possibility of antiphonal performance. ${ }^{67}$ Since it immediately follows the Peri Pascha, it has been suggested that it may have been used as part of the paschal liturgy, perhaps 'chanté après le baptême et avant l'agapeeucharistie'. ${ }^{68}$ Othmar Perler considers it likely that Melito is the author of the hymn. Even if this remains unprovable, a close and early connection between the Peri Pascha and the hymn seems highly likely. ${ }^{69}$ Certainly, the appearance of 1 Peter and the Peri Pascha, as in C-S, suggests that the paschal/Easter theme was again a prominent reason for the selection and collection of these texts.

A number of proposals have been made regarding the theological motivation or thematic focus that led to the creation of the entire codex which, in its final form, now also included the Apology of Phileas and Greek Psalms 33-34 (section II). Victor Martin, editor and translator of the Apology of Phileas in the Papyrus Bodmer series, proposed that the texts were united by their character as 'theological literature', developing and defending aspects of orthodox Christian doctrine. ${ }^{70}$ However, as Kim Haines-Eitzen points out, 'Martin's explanation... has the disadvantage of being so general that one wonders what early Christian literature would not fit in the category of "theological literature", or what third and fourth century Christian writings are not concerned in some way with the questions of doctrine-particularly in the form of controversies over "orthodoxy" and "heresy"'. ${ }^{71}$ Moreover, so far as 1 Peter is concerned, we might note that it is hardly concerned with any explicit rebuke of 'heretics', unlike Jude and 2 Peter. Nonetheless, as we have already seen, Martin's suggestion has some merit, at least so far as the combined force of sections I and III of the codex are concerned.

Haines-Eitzen's own proposal is that 'the most pervasive theme in the texts gathered into this codex is that of the body', a proposal cautiously affirmed to a degree by Wasserman. ${ }^{72}$ However, this proposal also fails convincingly to capture a unifying theme. In the first place, to be even plausibly considered, the motif of the 'body' must be understood in immensely broad and diverse ways-Haines-Eitzen notes, for example, the Nativity's insistence that Jesus was born in the flesh, the spiritualised notion of the flesh in the 11th Ode of Solomon, the polemic against those who defile the flesh in 2 Peter and the

67 So Testuz, Papyrus Bodmer X-XII, 73.

68 Perler, Méliton, 129.

69 See O. Perler, Ein Hymnus zur Ostervigil von Meliton? (Papyrus Bodmer XII) (Freiburg: Universitätsverlag Freiburg Schweiz, 1960). Cf. Perler, Méliton, 128-9.

70 Martin, Papyrus Bodmer XX, 9-10.

71 K. Haines-Eitzen, Guardians of Letters: Literacy, Power, and the Transmitters of Early Christian Literature (Oxford: Oxford University, 2000) 103.

72 Haines-Eitzen, Guardians of Letters, 103; Wasserman, 'Papyrus 72', 147. 
theme of persecution and martyrdom in the Apology and the two Psalms. ${ }^{73}$ Thus, like Martin's category of 'theological literature', the motif of the body becomes too diffuse to capture any supposedly clear common thread. The theme of the body $(\sigma \hat{\omega} \mu \alpha)$ as such is, after all, hardly apparent in these texts, not least 1 Peter (from which the word is absent).

Wasserman assesses these earlier proposals, and adds the possibility of some 'liturgical connection between some of the writings' ${ }^{74}$ - a connection he unfortunately leaves unspecified-and also 'several characteristics typical of incipient orthodoxy... especially in the area of Christology' (cf. above). ${ }^{75}$ However, Nicklas and Wasserman are cautious about the possibility of identifying any specific theme which might explain the formation of the whole collection. ${ }^{76}$ In their view, the BMC may occupy 'eine Mittelstellung zwischen Codices, deren Texte ganz offensichtlich unter einem die Einzeltexte recht eng verknüpfenden leitenden Thema verzahnt sind, und solchen, bei denen keinerlei innerer Zusammenhang erkennbar ist... Das Manuskript bleibt rätselhaft'. ${ }^{77}$

The earlier proposals by Wolfgang Wiefel, however, are also worth our attention. Wiefel distinguishes the two phases of the codex's development and attempts to provide a Sitz im Leben for each. ${ }^{78}$ The texts collected in the first phase, during the third century (sections I and III above), constituted a 'Privatanthologie'79 for personal use, characterised by a 'deutlich antihäretischer Tendenz'. ${ }^{80}$ In the second phase, during the early fourth century, when section II was added, the codex was likely used for private reading at festival times, particularly at Easter. ${ }^{81}$ The change evident in this second phase may thus be summarised, 'daß die ursprünglich mit antihäretischer Zielsetzung angelegte Anthologie zur erbaulichen Vorlesung an Festtagen bestimmt wird'. ${ }^{82}$

Certain aspects of Wiefel's proposals seem somewhat unconvincing. The suggestion that the codex was intended for personal/private use, on the basis of its relatively small size, is not necessarily to be accepted. ${ }^{83}$ There is some merit, as

73 Haines-Eitzen, Guardians of Letters, 103-4.

74 Wasserman, 'Papyrus 72', 154; cf. 146.

75 Wasserman, 'Papyrus 72', 147; cf. 154.

76 Wasserman, 'Papyrus 72', 154; Nicklas and Wasserman, 'Theologische Linien', 185-8.

77 Nicklas and Wasserman, 'Theologische Linien', 185, 188.

78 Wiefel, 'Kanongeschichtliche Erwägungen', 290-3. Cf. Nicklas and Wasserman, 'Theologische

Linien', 166, who describe Wiefel's proposal as '[e]inen sehr komplexen Vorschlag'.

79 Wiefel, 'Kanongeschichtliche Erwägungen', 297.

80 Wiefel, 'Kanongeschichtliche Erwägungen', 299.

81 Wiefel, 'Kanongeschichtliche Erwägungen', 299-300.

82 Wiefel, 'Kanongeschichtliche Erwägungen', 300.

83 The dominant context for reading/hearing — not least given the low rates of literacy-would have been the congregational meetings. Moreover, the miniatures made specifically for private use were often much smaller than either BMC or C-S: see H. Y. Gamble, Books and 
we have seen, in seeing the collection as a presentation of emerging orthodoxyto which 1 Peter makes a clear contribution-with defence against heretics and false teachers also a prominent concern (here 2 Peter is more pertinent). But unlike Jude, 2 Peter, and 3 Corinthians, 1 Peter is plainly unpolemical, and has no explicit concern to combat false teaching. The proposed shift to a Paschal focus with the addition of section II is also less than convincing, since it seems hardly related to the content of the texts added at this point, particularly the Apology of Phileas. ${ }^{84}$ It is rather Melito's Peri Pascha and 1 Peter that are central here. While this means that Wiefel's attempt to identify distinct motives and uses at different stages in the codex's history is unconvincing, his linking of the contents with an Easter theme and the Paschal celebrations remains of interest. 1 Peter is crucial here. Indeed, Wiefel goes on to note that, if we add 1 Peter to Melito's Peri Pascha, 'so entfällt die Hälfte des Bestandes (85 von 167 erhaltenen Blättern) auf Texte mit Osterbezug' ${ }^{85}$

While Nicklas and Wasserman see the inclusion of Psalms 33-34 (LXX) along with 1-2 Peter as most likely a coincidence, ${ }^{86}$ Wiefel explains the inclusion of Psalms 33-34 on the basis of a link between Psalm 33 and 1 Peter. Noting that the Psalm is cited twice in 1 Peter-in 2.3 and 3.10-12, the latter being 'das längste AT-Zitat im 1. Petr. überhaupt'-Wiefel raises the question whether 1 Peter was understood as a homily on Psalm $33 .^{87}$

Indeed, beyond the important citations (and possible echoes) of Psalm 33 in 1 Peter, there are also close thematic resonances between these two Psalms and 1 Peter. Both Psalms depict the cry of the righteous Davidide to God, for deliverance from those who persecute him and cause him suffering. As such they contain christologically relevant motifs, and were evidently taken to be of messianic significance by early Christians (cf. the quotation of Ps 33.21 [LXX] in John 19.36). They are also particularly relevant to the situation of people suffering rejection and persecution in a hostile world (cf. 4 Macc 18.15). 1 Peter explicitly describes the suffering Christ as a model for Christian discipleship, just as these Psalms depict the righteous sufferer in the line of David, who endures suffering confident of God's just vindication. These two Psalms offer an excellent OT source to connect two themes central to 1 Peter:

Readers in the Early Church: A History of Early Christian Texts (New Haven and London: Yale University, 1995) 332 n. 101.

84 Cf. Nicklas and Wasserman, 'Theologische Linien', 167, who note that Wiefel's theory leaves unclear what role the Apology has in the collection.

85 Wiefel, 'Kanongeschichtliche Erwägungen', 300. On the total number of pages in the codex, see above n. 45 .

86 Cf. Nicklas and Wasserman, 'Theologische Linien', 170; I think this underestimates the likelihood that literary and thematic connections were perceived, on which see below.

87 Wiefel, 'Kanongeschichtliche Erwägungen', 299. He does not, however, refer to W. Bornemann's much earlier proposal to this effect, on which see below. 
the suffering and vindication of Christ, and the suffering and vindication of God's righteous people. Furthermore, Psalm 33 (LXX) contains another theme of great importance to 1 Peter, that of 'doing good' (Ps 33.15 [LXX], quoted in 1 Pet 3.11).

There is also more to say about the significance of the Apology of Phileas, quite possibly the key to the formation of the codex in its final form. It is interesting to note that in the other extant Greek manuscript of this text, Papyrus Chester Beatty $\mathrm{XV}$, which dates from roughly the same time as (this part of) BMC (i.e. early to mid-fourth century), Phileas is also bound together with a collection of Greek Psalms. ${ }^{88}$ Even more important for our consideration here is the content and character of the Apology of Phileas (elsewhere called the Acts of Phileas). It is a martyrdom account which details the repeated questioning of Phileas by the prefect Culcianus. Culcianus repeatedly urges Phileas to sacrifice to the gods-and on one occasion to swear an oath, probably to the genius of the emperors ${ }^{89}$-while Phileas gives a range of reasons for his firm and repeated refusal. Although the death of Phileas is not narrated in the BMC version (contrast the Chester Beatty Papyrus and the Latin version), ${ }^{90}$ it is clear that attempts by the whole court to persuade him will not change his resolute refusal to comply with the prefect's request.

A comparison with C-S is striking: there, along with Melito and 1 Peter, we had 2 Macc 5-7, an account of the Jewish martyrs; here, along with Melito and 1 Peter, we have an account of the trial of a recent Christian martyr. The thematic resonances which cluster in BMC, and specifically around 1 Peter, are, then, closer than has been recognised. Wiefel, we recall, noted that when the pages of Melito and 1 Peter were added together, half of the BMC comprised texts with an Easter connection. However, if we now add Psalms 33-34, texts which clearly focus on the theme of the suffering and hope for vindication of the Davidic righteous one, and the Apology of Phileas, a Christian martyrology, then over a hundred pages of the codex (101 of the 183 that are extant) contain texts relating to the themes of the paschal suffering of Christ, and the related suffering of his people in a hostile world. The parallel with the focal themes of C-S is close indeed.

There are also some specific points of connection with 1 Peter. Just as Phileas is here presented as an apologia (the opening phrase is: $\alpha \pi \mathrm{o} \lambda \mathrm{o} \gamma \varepsilon 1 \alpha$ [sic] $\phi \imath \lambda \varepsilon \mathrm{ov}$ $\varepsilon \pi 1 \sigma \kappa о \pi о v \theta \mu о v \varepsilon \omega \varsigma)$, so the addressees of 1 Peter are instructed 'always to be ready to offer an $\alpha \pi \circ \lambda \circ \gamma i \alpha$ to anyone who demands an account ( $\lambda$ ó $\gamma \circ \varsigma$ ) from you' (3.15). ${ }^{91}$ And as with martyr-acts elsewhere, so the Apology of Phileas

88 See Pietersma, Acts of Phileas, 11.

89 See BCM col. 7, lines 7-12 (from Pietersma's new edition). In P. Chester Beatty XV, the oath is explicitly 'by the genius of the emperors' ( Phileas, 42).

90 See Pietersma, Acts of Phileas, 18-20.

91 The possibly legal nuances of this language in 1 Peter have long been noted, though recent commentators have tended to suggest that the context implied here is everyday rather than judicial (e.g. Elliott, 1 Peter, 627-8; N. Brox, Der erste Petrusbrief [EKKNT 21; Zürich/ 
epitomises the kind of 'polite resistance' (as I have elsewhere termed it) ${ }^{92}$ that 1 Peter calls for in its instruction that the emperor should be honoured, but God (alone) should be worshipped (2.17). The refusal to sacrifice (and to swear) is the central focus in Phileas.

We cannot claim, then, that a single theme or theological motif unites every one of the diverse texts collected in BMC. Nonetheless, there are a number of aspects of the codex's content that are significant for understanding the way early editors/readers understood the themes and content of 1 Peter.

First, linked with 2 Peter, and then with the other texts in section I of the codex, 1 (and 2) Peter provides a body of Petrine teaching which is valuable and instructive for an emerging Christian orthodoxy, not least in its battles against what is perceived as false teaching and heresy.

Second, there is the prominent focus on Easter themes central to Christian faith and discipleship. As in C-S, there is the striking collocation of 1 Peter and Melito's Peri Pascha. This would seem to indicate that early editors, like modern scholars, recognised the thematic (and textual?) resonances connecting the two works, and their common focus on the themes of Christ's suffering, death and vindication. The linking of 1 Peter with Psalms 33-34 not only highlights still further the paschal theme, but also connects this christological motif with the suffering of God's people in a hostile world, their following of the one who suffered for them and their hope of salvation and vindication. Given the clear use of Psalm 33 in 1 Peter, there is also an intertextual as well as a thematic relationship. The inclusion of the Apology of Phileas, perhaps the key to the making of the final collection, indicates, as in C-S, the thematic link between the suffering of Christ and the suffering of God's faithful people. In short, while the clear thematic coherence that characterises C-S is less evident in BMC, there is still a good deal to suggest a similar focus linking a number of texts with themes central to 1 Peter.

\section{The Significance of C-S and BMC for the Interpretation of 1 Peter}

It remains to consider the significance of these early codices for the interpretation of 1 Peter, particularly in relation to a history of research in

Braunschweig: Benziger; Neukirchen-Vluyn: Neukirchener, 3rd ed. 1989], 159-60; O. Knoch, Der erste und zweite Petrusbrief. Der Judasbrief [RNT; Regensburg: Friedrich Pustet, 1990], 97; K. H. Jobes, 1 Peter [BECNT; Grand Rapids, MI: Baker Academic, 2005], 230).

92 D. G. Horrell, 'Between Conformity and Resistance: Beyond the Balch-Elliott Debate Towards

a Postcolonial Reading of 1 Peter', Reading 1 Peter with New Eyes: Methodological Reassessments of the Letter of First Peter (ed. R. L. Webb and B. Bauman-Martin; LNTS 364; London and New York: T\&T Clark, 2007) 111-43. 
which proposals concerning a baptismal, homiletical, liturgical or paschal origin for 1 Peter, after a period of popularity, have in more recent decades come to be decisively rejected..$^{93}$

First to propose that 1 Peter contained a baptismal homily (in 1.3-4.11) was Richard Perdelwitz. ${ }^{94}$ This view of the letter was also developed (independently) by W. Bornemann, who argued that 1 Pet 1.3-5.11 (the letter frame being added later), 'ursprünglich eine Taufrede war, und zwar im Anschluß an Psalm 34 [LXX 33] um das Jahr 90 von Silvanus in einer Stadt Kleinasiens gehalten'.$^{95}$ Much of Bornemann's article was devoted to an attempt to demonstrate a large number of allusions to this Psalm in the text of 1 Peter.

The view of 1 Peter's origin as a baptismal homily became popular, and not only in German scholarship. ${ }^{96}$ Herbert Preisker developed a liturgical analysis of the letter as a literary record of a baptismal service, an analysis which was enthusiastically endorsed by F. L. Cross. ${ }^{97}$ Cross agrees with Perdelwitz, Bornemann, Preisker and others that 1 Peter is, in large part at least, a baptismal homily, ${ }^{98}$ but goes beyond this theory in proposing that the baptismal context is specifically that of the Paschal Baptismal Eucharist.

Some subsequent work presented similar analyses, ${ }^{99}$ but criticisms were also expressed. ${ }^{100}$ The ingenious but speculative proposals of Preisker and Cross came increasingly to be seen as unconvincing- impressive in their breath-taking ingenuity', as J. N. D. Kelly puts it ${ }^{101}$-and as obscuring rather than highlighting the central concerns and themes of the letter. Recent scholarship has almost unanimously come to reject the liturgical and homiletical theories of earlier scholarship, together with their proposals for literary partition and a baptismal connection. In his recent and magisterial commentary, John Elliott concludes his review of scholarship on the genre and integrity of the letter thus: ' 1 Peter from the outset was conceived,

93 See Elliott, 1 Peter, 7-12 for a concise but thorough treatment of this history of research.

94 R. Perdelwitz, Die Mysterienreligion und das Problem des 1. Petrusbriefes (Giessen: Alfred Töpelmann, 1911) 19, 22.

95 W. Bornemann, 'Der erste Petrusbrief-eine Taufrede des Silvanus?' ZNW 19 (1920) 143-65 (146).

96 See Elliott, 1 Peter, 8, for a list.

97 H. Priesker, 'Anhang zum ersten Petrusbrief', in H. Windisch, Die katholischen Briefe (HNT 15; Tübingen: Mohr, 3rd ed. 1951) 152-62 (157). F. L. Cross, I Peter: A Paschal Liturgy (London: Mowbray, 1954).

98 Cross, 1 Peter, 28-35.

99 E.g. M.-E. Boismard, Quatre hymnes baptismales dans la première épître de Pierre (LD 30; Paris: Cerf, 1961).

100 Notably C. F. D. Moule, 'The Nature and Purpose of 1 Peter', NTS 3 (1956-7) 1-11; T. C. G. Thornton, 'I Peter, a Paschal Liturgy?', JTS 12 (1961) 14-26; D. Hill, 'On Suffering and Baptism in I Peter', NovT 18 (1976) 181-9.

101 J. N. D. Kelly, A Commentary on the Epistles of Peter and Jude (BNTC; London: A. \& C. Black, 1969) 18, cited in Elliott, 1 Peter, 10. 
composed, and dispatched as an integral, genuine letter. This conclusion represents the position of the vast majority of recent research on 1 Peter'. ${ }^{102}$

There is perhaps some irony in the fact that those who proposed a paschal or baptismal setting for 1 Peter, or noted specifically its connections with Melito or with Psalm 34 (LXX 33), wrote before the discovery of the manuscripts in which these texts were collected together with 1 Peter, while the rejection of their proposals became established precisely in the period shortly after the publication of the Bodmer Miscellaneous Codex. ${ }^{103}$ Or, to raise the issue in a different way, while recent commentators on 1 Peter have paid little attention to the significance of the manuscript contexts in which the earliest copies of 1 Peter have been found, those whose attention is primarily focused on these manuscripts sometimes echo earlier views of 1 Peter, in a way which can sound dated to those familiar with recent scholarship on the letter. Thus, Willis opens his introduction to the C-S text of 1 Peter with the following words: 'In an early mixed codex the selection of the texts for which was the theme of the Pasch, it is not surprising to find 1 Peter, long recognized as a baptismal homily appropriate to the Easter season. ${ }^{104}$

How far, then, should these earliest manuscripts of 1 Peter cause us to revise our views of the letter, and perhaps reassess the proposals from an earlier phase of Petrine scholarship?

(1) We should not, I think, reject the strong consensus of recent scholarship that 1 Peter is a genuine letter, and a literary unity. Nonetheless, there is perhaps a somewhat more blurry line between epistolary and liturgical origin than the recent consensus suggests. For a start, as a letter which has long been seen as 'une Épître de la Tradition', incorporating a wide range of early Christian traditions and materials, 1 Peter may well include material that has been formed and shaped in liturgical contexts, even if the precise identification of such materials is not possible with any confidence. ${ }^{105}$ Moreover, the immediate

102 Elliott, 1 Peter, 11. Cf. also K. M. Schmidt, Mahnung und Erinnerung im Maskenspiel. Epistolographie, Rhetorik und Narrativik der pseudepigraphen Petrusbriefe (HBS 38; Freiburg/Basel/Vienna: Herder, 2003) 157; R. Feldmeier, The First Letter of Peter: A Commentary on the Greek Text (Waco, TX: Baylor University, 2008) 28-32. Feldmeier sees 'no reason to doubt the unity of 1 Peter' (30) but leaves more open the question as to whether it was originally sent as a letter or only clothed in this form (32).

$103 \mathrm{C}-\mathrm{S}$, of course, has only been relatively recently published.

104 Willis, 'Letter of Peter', 137. Cf. Nicklas and Wasserman, 'Theologische Linien', 183, writing on the contents of BMC: 'Eines der entscheidenden Themen des 1.Petrusbriefes ist die Taufe'. It should be noted, though, that Willis continues the comments cited above as follows: 'But whatever may be one's view of the text as a baptismal sermon or liturgy, its inclusion in the Crosby-Schøyen codex confirms at least that the scribe or organizer of the codex considered the epistle Paschal in character' (137).

105 C. Spicq, Les Épittres de Saint Pierre (SB; Paris: Gabalda, 1966) 15. See further D. G. Horrell, 'The Product of a Petrine Circle? A Reassessment of the Origin and Character of 1 Peter', JSNT 86 (2002) 29-60. 
reception of a letter is in a liturgical context, in the sense that it is read (and intended to be read) to a congregational gathering. From the earliest times the dominant Christian context for the reading of scriptural texts and other letters and communications was the ecclesial meeting (cf. 1 Thess 5.27; Col 4.16; 1 Tim 4.13; Rev 1.3). ${ }^{106}$ And it was not only texts from the Jewish scriptures and the (later canonised) NT texts that continued to be read in early Christian worship; other letters and valued writings were also included (cf., e.g., Eusebius $H E 3.3 .6 ; 3.16 ; 4.23 .11$ ). Martyr-acts too were read in the context of Christian meetings, perhaps from as early as the second century. ${ }^{107}$ It is unlikely that 1 Peter originated as a baptismal homily on Psalm 33, as Bornemann argued, but the Psalm, the use of which may have been known from the context of congregational worship, has clearly enough influenced the author of the letter, even if not to the extent that Bornemann argued. ${ }^{108}$ The BMC suggests that this intertextual and/or thematic link between 1 Peter and Psalms 33-34 was soon recognised by readers of the epistle.

It is impossible to be certain how the particular codices we have considered here were used, whether liturgically-specifically at Easter, or throughout the year?-or, say, for catechetical instruction. Bethge, for example, regards C-S as 'ein liturgisches Buch für die Osterzeit'. ${ }^{109}$ Wasserman notes 'a liturgical connection between the 11th Ode, Melito's Homily, the hymnal fragment and 1 Peter' in BMC. He is uncertain whether 'the Bodmer codex was actually used in church services' but nonetheless sees the liturgical connections as likely explained 'by the fact that these texts were transmitted in a liturgical context'. ${ }^{110}$ The appearance of two psalms in the collection would also support a liturgical use. C-S, with its clear and well-spaced text, and its tight thematic focus, perhaps more strongly implies a liturgical use, while the less polished presentation of the BMC text, and its wider range of topics and material, might possibly suggest a use in teaching and instruction, whether in congregational or private settings.

But even if we do assume some kind of liturgical/congregational use, this is, of course, quite different from the view which sees in the text of 1 Peter the record of a (baptismal/eucharistic/paschal) liturgy. Finding 1 Peter in early liturgical use does not imply that the document originated as a liturgical order, later set within an epistolary frame. It is important to distinguish between the search for

106 See further Gamble, Books and Readers, 205-8, 211-18; L. W. Hurtado, 'The New Testament in the Second Century: Text, Collections and Canon', Transmission and Reception: New Testament Text-Critical and Exegetical Studies (ed. J. W. Childers and D. C. Parker; Piscataway, NJ: Gorgias, 2006) 3-27 (11-14).

107 Gamble, Books and Readers, 218.

108 See S. Woan, 'The Psalms in 1 Peter', The Psalms in the New Testament (ed. S. Moyise and M. J. J. Menken; London \& New York: T\&T Clark, 2004) 213-29.

109 Bethge, 'Crosby-Schøyen-Codex', 257.

110 Wasserman, 'Papyrus 72', 146. 
the origins of 1 Peter and the early interpretation and use of the letter. Early twentieth-century scholarship on 1 Peter rightly and astutely recognised in 1 Peter paschal themes, and connections with Melito and Psalm 33. Where it went wrong was in seeing these themes and connections as indications of the origins of the letter, in homily or liturgy, the addition of an epistolary frame turning these materials into the form of a letter.

(2) Perhaps the main way in which these manuscripts of 1 Peter make a contribution to our understanding of the letter is in indicating what early interpreters took to be its central themes and theological focus. The two earliest copies of 1 Peter, C-S in particular, indicate that some of the earliest interpreters of the letter found it full of paschal themes, seeing connections with Melito and (in BMC) the Psalms. They also found it a text resonant with the themes of persecution and martyrdom, and the suffering of God's people in the world, a suffering that imitates that of Christ. This thematic focus is less consistently evident in $\mathrm{BMC}$, but is nonetheless prominent, as we have seen above.

In identifying such themes as central to the letter, these codices-products and reflections of a somewhat later time and context-do not, of course, allow us to assume that these were also in the mind of the author of 1 Peter. But they do provide a view, an interpretation of the letter, which can, not entirely unlike exegetical works and commentaries (also reflections of later times and contexts), point us to the theological centre of the letter and to its dominant themes and concerns-whether or not these were consciously intended by its author. In identifying as the central themes of 1 Peter the suffering and vindication of Christ, and the related suffering and hope of his faithful people in a hostile world, the producers of these early codices concur with modern commentators. ${ }^{111}$ This in itself illustrates how these early manuscripts constitute a valuable and fascinating part of the history of interpretation of 1 Peter, an illuminating pointer to the dominant themes of the letter.

111 E.g., Elliott characterises 1 Peter as follows: 'First Peter is, in a sense, an Easter letter. The basis for the hope it celebrates, and the impetus for the creation of the distinctive community it describes, are grounded in God's resurrection of Jesus Christ from the dead and the regeneration of those who confess him as Lord... It is most appropriate, therefore, that it is 1 Peter to which the church listens in its liturgical celebration of the Sundays of the Easter season' (J. H. Elliott, Conflict, Community, and Honor: 1 Peter in Social-Scientific Perspective [Eugene, OR: Cascade, 2007], 2-3. 